\title{
A figura da bruxa sob a perspectiva teórica de René Girard, na poesia de Amanda Lovelace
}

\author{
Roseli Hirasike* \\ Vera Lúcia Bastazin"
}

\section{Resumo}

Este artigo aborda a figura da bruxa na literatura e sua presença nos poemas do título A bruxa não vai para a fogueira neste livro, de Amanda Lovelace. Partimos de um breve panorama dos estudos de Joseph Campbell, focando, em seguida, os conceitos de poder como objeto de desejo e a teoria do desejo mimético de René Girard. Apresentamos dados históricos e a origem etimológica do termo bruxa, importantes para a interpretação em foco, no qual o poder desejado é aquele de controle do fogo destruidor, em oposição ao fogo transformador, também presente na base dos mitos das deusas-bruxas. Finalmente, procedemos à análise da temática feminista dos poemas e os parâmetros que nos apontam o bode expiatório, surgido na linha traçada entre a bruxa das fogueiras da Inquisição e o gênero masculino na atualidade, representado metaforicamente nos poemas como "o cara dos fósforos".

Palavras-Chave: Bruxa; Mitologia; Feminismo; Mito e desejo mimético; Amanda Lovelace.
* Graduada em Letras, tradutor e intérprete/inglês, pelo Centro Universitário Ibero-Americano (1989) e em Direito pela Universidade de Guarulhos (1996). Mestre em Literatura e Crítica Literária pela Pontifícia Universidade Católica de São Paulo (2014). Tema da dissertação: $\mathrm{O}$ feminino revelado em Clarice Lispector. Atualmente ministra cursos livres de Introdução à Mitologia e Mitos na Literatura e participa do Grupo de Pesquisa inscrito no Diretório dos Grupos CNPq Categorias da Narrativa, na PUC-SP, sob a Coordenação da Profa. Vera Bastazin. E-mail: hirasike@gmail.com

** Possui graduação em Língua e Literatura Francesas e Língua e Literatura Portuguesas; Mestrado e Doutorado em Comunicação e Semiótica/ Literatura, pela PUC/SP, onde atualmente é Professora-Associada. Participou nessa mesma Universidade, da fundação do Programa de Pós-Graduação em Literatura e Crítica Literária (Mestrado e Doutorado), do qual foi coordenadora por quatro gestões. Ministra aulas nos cursos de Graduação em Letras e do Programa de Pós-graduação em Literatura e Crítica Literária. Sua atuação ocorre nas áreas de Teoria Literária, Literatura Comparada - destacadamente Literatura Brasileira e Portuguesa. Realizou estágio Pós-Doutoral, com Bolsa FAPESP, na Universidade do Minho, em Braga, sob a supervisão do Prof. Dr. Vitor Manoel de Aguiar e Silva. Suas pesquisas estão centradas no romance contemporâneo. Participou da Diretoria da ABRALIC (2007-08) e da Diretoria da ANPOLL (2015-16). Publicou, nos últimos anos "Mito e Poética na Literatura Contemporânea - um estudo sobre José Saramago". Ateliê Editorial, 2006,

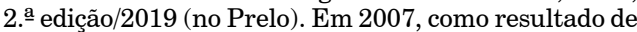
pesquisa desenvolvida com professores de Filosofia, História e Literatura, lançou "Literatura Infantil e Juvenil: uma proposta interdisciplinar". Editora Articulação Universidade/Escola; em 2011, "Poesia Contemporânea; Brasil/Portugal". São Paulo: EDUC/ CAPES; e, em 2017, "Literatura e Ensino: territórios em diálogo". São Paulo, EDUC/Capes . Possui, também, vários ensaios, artigos e capítulos de livros publicados no Brasil e no exterior. É líder do Grupo de Pesquisa "Categorias da Narrativa", inscrito no Diretório do Grupos de Pesquisa do Brasil/ CNPq, desde 2008. E-mail: vbastazin@uol.com.br

Data de submissão: ago. 2021 - Data de aceite: out. 2021

http://dx.doi.org/10.5335/rdes.v17i3.11214 


\section{Introdução}

Ao longo das profundas transformações sociais ocorridas nos últimos anos, observam-se, entre outras manifestações, a efervescência dos direitos da mulher, assim como a importância de seu papel histórico dentro das instituições sociais, políticas e religiosas. Acompanhando este processo, que tem se intensificado cada vez mais em nossos dias, observa-se também o interesse crescente e diversificado dos estudos sobre a mulher, referidos como estudo do feminino, inserido nas questões de gênero. Este campo de investigação mostra variados, e até opostos, pontos de vista. Neste artigo, focados na área da Teoria e da Crítica Literária, temos consciência do quanto ampla pode ser nossa abordagem, todavia, nossa intenção é contribuir com a temática da Mitologia na Literatura e suas figuras femininas questão muito rica e instigante para os estudos literários.

Desde tempos primordiais, o homem busca incessantemente pelo poder. Reflitamos um pouco, neste momento, sobre as diversas facetas a que o vocábulo possa nos remeter, uma vez que destacamos a sua disputa como objeto de desejo.

Para Joseph Campbell (2004) o poder que o homem conquista pode ser aquele que busca em si mesmo ou aquele que vem de fora e o submete. Em sua obra A Jornada do Herói, o autor nos fala do percurso do indivíduo até a conquista de seu objetivo. Tal estrutura é adotada em roteiros os mais diversos na literatura, pois como afirma o mitologista, toda história tem um herói. Seguindo esta linha de estudos, observamos em suas proposições que muitos heróis são mitologizados, ou seja, suas histórias ganham o status de modelo para a humanidade, uma das definições de mito apresentada em seu $O$ Poder do Mito. O poder é erigido na jornada do herói, por meio de autoconhecimento e da superação de obstáculos naturais e/ou impostos por seus opositores. Nesses estudos, Campbell nos mostra, ainda, como a incompreensão do poder de um mito pode submeter o homem a um modelo, transformador, mas que o distancia de sua essência e individualidade (CAMPBEL, 1991, p.24).

$\mathrm{Na}$ Mitologia, portanto, o homem percebe que o caminho rumo ao desconhecido exige uma jornada individual, entremeada de momentos de transição e de escolhas, referidos como ritos de passagem. Por si só, a jornada conduz o homem, não ao encontro de um resultado estanque, mas à consciência da formação de seu poder. Os derradeiros momentos dos ritos de passagem formam seu caráter e lhe agregam autoconhecimento, autoconfiança e clareza em seus propósitos, tornando-o consciente de seu poder e de suas responsabilidades.

Desejando tocar o mistério da vida e de sua origem, a humanidade produziu um vasto mundo de mitos, povoado por 
exemplos de convivência, conflitos, tragédias, vitórias e derrotas no processo existencial. Por meio de símbolos, o estudo da Mitologia permite acesso a identidades culturais para compreensão da natureza humana e formação da consciência coletiva.

No Prefácio ao Mitologia Grega, de Junito Brandão, Carlos Byington faz a seguinte analogia:

Os pais ensinam aos filhos como é a vida, relatando-lhes as experiências pelas quais passaram. Os mitos fazem a mesma coisa num sentido muito mais amplo, pois delineiam padrões para a caminhada existencial através da dimensão imaginária. (1994, p. 9)

O conhecimento aprofundado dos mitos como referência na construção da personagem e na estruturação da narrativa literária parece relevante para nos capacitar à análise cultural das suas diferentes formas de manifestação na literatura. Articulações entre Mitologia e Literatura são bem antigas, além de bastante ricas. Temos observado alguns desvios interpretativos sob o manto da definição de criações literárias baseadas ou inspiradas em determinados mitos. Muitos dirão que o próprio mito sofre alterações diversas, desde estruturais até culturais e políticas. É verdade. Mas o trabalho de pesquisa e crítica pode e deve se debruçar sobre os meandros de variação de um tema, a partir de sua base ou moral histórica originária. Não se trata de ditar o permitido ou não no universo simbólico-imagético do mito, mas de colocar luz sobre o objetivo da inserção deste em uma narrativa, conforme seu contexto. Não há literatura neutra, defendeu Jean Paul Sartre em seu O que é a literatura e, assim, sem pretender nos aprofundarmos na obra, apenas a mencionamos como observação introdutória a nossa abordagem do livro A bruxa não vai para a fogueira neste livro, de Amanda Lovelace, publicado em 2018.

Partimos, portanto, da observação da maleabilidade das figuras míticas na literatura e debruçamo-nos, em particular, sobre a bruxa, em suas versões contemporâneas, nas quais permanece, ainda, como personagem polêmica e bipolar, isto é, ora poderosa a redimir todo o sofrimento do subjugo das mulheres; ora cruel, vingativa e egoísta. Inúmeros são os exemplos que poderíamos aqui elencar, seja nos roteiros cinematográficos, ou mesmo de seriados e de musicais, trazendo criações nas quais Malévola, apresentada, em princípio, como má, concede seu dúbio beijo maternal e traidor, para acordar a Bela Adormecida.

Todavia, neste artigo, centramos nosso olhar para as alusões às bruxas numa coletânea de poemas que passa a ser nosso objeto de observação. Apoiados na análise conjunta das teorias de fundamento para o presente trabalho, pontuamos a inversão de papéis no mito da bruxa enviada às fogueiras, em relação ao homem, ou universo masculino, na atualidade. 


\section{Vamos às bruxas}

Uma infinidade de deusas, dos mais diversos panteões e mitologias, vem sendo estudada pela psicologia, pela antropologia e, recentemente, pela neurociência por meio de análise dos modelos de mulheres ali representadas e dotadas de poderes para controlar o mundo ao seu redor. Assim, o conhecimento dos atributos de deusas mitológicas e arquetípicas inaugura um modo de se perfilarem mães, amantes, guerreiras, guardiãs destes ou daqueles atributos e valores individuais e sociais. As antigas deusas foram conhecidas, celebradas e cultuadas como faces variadas de uma deidade mater e, mais tarde, também estudadas em seus mitos, como arquétipos do feminino. Deusas e bruxas se misturaram. Ora as bruxas se confundem com as próprias deidades, ora com as iniciadas adoradoras das deusas e praticantes de magia.

A professora e psicoterapeuta Jennifer Barker Woolger lado a lado com o professor Ph. D. e analista junguiano, Roger J. Woolger, afirmam, na obra $A$ Deusa Interior (2007), - baseados em estudos da psicologia sobre a psique feminina - o surgimento de novas abordagens de compreensão do feminino em nossa sociedade. É notório, em diversos ramos da ciência e da literatura o surgimento de uma nova consciência feminina. Interessa-nos analisar as implicações desse movimento na literatura que confronta os paradigmas do mito com a mulher contemporânea.

Numa abordagem etimológica, historiadores e antropólogos apresentam diferentes versões para a origem da palavra bruxa. $\mathrm{O}$ vocábulo nas línguas de origem latina - idioma inicialmente usado como oficial na Igreja Católica -, aparenta advir de "bruciare", verbo do italiano que significa queimar. Diferentemente, no idioma inglês, de origem germânica, o vocábulo "witch" significa mulher dotada de poderes malignos e sobrenaturais. Todavia, conforme estudos específicos de etimologistas, como Anatoly Liberman (2009), da Universidade de Minnesota, o vocábulo que pode ser originário de palavra do inglês arcaico, anterior ao Cristianismo, significaria sábio, mágico ou auspicioso, indicando que os sentidos negativos lhe foram acrescentados, posteriormente, mediante agregação ou substituição cultural ao seu campo semântico.

De fato, a definição da Igreja para a palavra bruxa é bem posterior aos cultos das deusas da Mitologia e, certamente, não contempla a posição histórica das matriarcas pagãs.

Para a historiadora Maria Nazareth A. de Barros (2001, p. 327), houve um momento de crescimento do valor feminino resultante do resgate da imagem de uma deidade mater, ambivalente, como seu modelo. Movimentos religiosos e literários nos séculos XII e XIII 
consolidaram o poderio feminino, quer na cultura popular, como nos meios da elite intelectual, colocando de lado a discriminação da mulher e valores como a virgindade e castidade. $\mathrm{O}$ amor cortês passa a ser valorizado e a mulher é reinserida na sociedade como importante companheira a ser conquistada.

Barros destaca como a exposição da dualidade existente em todo e qualquer ser humano, do bem e do mal, pressionara as religiões monoteístas. Afinal, eram aquelas erigidas sobre pilares do poderio masculino para guardar o preceito primeiro da existência de um Deus único, de bondade absoluta, diferentemente dos deuses antigos ambivalentes. A criação do homem à sua imagem e semelhança, portanto, encontrava reparo no conceito de pecado, o qual, diante dos preceitos religiosos que condenavam o desejo sexual, apontava na sedução feminina um instrumento do mal. Assim a historiadora destaca a construção da fantasia de malignidade em torno do poder feminino, o qual, por seu fascínio e medo, passaria a ser controlado com medidas severas (BARROS, 2001, p. 325).

A igreja havia tolerado as práticas pagãs, politeístas, também caracterizadas pelo culto à denominada Deusa Mãe. Entretanto, horrorizava-se diante das práticas pagãs que consideram sagrados o corpo, a sexualidade e a fertilidade femininos. Isto porque, preceitos religiosos mais radicais da época, opunham o corpo à alma (BARROS, 2001, p. 334).
Assim, as bruxas, praticantes das religiosidades pagãs e do culto às diversas deusas ambivalentes, adoradas como faces da deidade mater, fatalmente viriam a ser perseguidas. E a elas comparadas todas as mulheres consideradas hereges, mesmo não praticantes da bruxaria.

Entre os séculos XIV e XVIII, após o período denominado Idade Média, a bruxaria foi considerada uma heresia e um crime sujeito à pena de morte. A perseguição às bruxas tem registros, também, na História da Roma antiga, período esse próximo do fim do Império, já que os Imperadores não viam seu poder e autoridade suficientemente protegidos da magia, ou do que se acreditava ser magia.

Ao final da Idade Média, são criados os Tribunais da Santa Inquisição e, como observado por muitos historiadores modernos, em consequência dos processos adotados por aquela instância julgadora, a bruxaria não mais é reconhecida como prática remanescente de uma religião pré-cristã. É considerada heresia e tratada como crime, nos moldes impostos pelos processos da Inquisição. Desta forma, quando a História busca naqueles processos e registros o significado de bruxaria, fatalmente, encontra a descrição então conferida às heresias.

$\mathrm{O}$ ato herético, combatido e penalizado pela Igreja Católica, é bom lembrar, não foi sempre condenável. Consistia na opção por determinado estudo e prática de uma filosofia, teoria ou ideia. Passa a 
ser considerado ato condenável e objeto de processo persecutório à medida que a Igreja decide não mais tolerar o estudo e interpretação de temas contrários aos seus dogmas. O herege era o dissidente da doutrina cristã. Daí a Igreja Católica, que na época detinha poder estatal e jurisprudência universal, ter criado um Tribunal para defesa de seus interesses. Ou seja, o Tribunal tinha poder de prender e julgar cristãos do mundo todo, e no âmbito estatal, prender qualquer um que ofendesse os interesses da Igreja.

A mulher de tradição matriarcal, líder de comunidades, praticante de outra religiosidade e ideais sociais, praticante dos cultos às deusas antigas, era considerada herege e, potencialmente condenável a morrer na fogueira - curiosamente o elemento que os próprios pagãos consideravam purificador, transformador e transmutador, no sentido simbólico advindo da forja de metais e das práticas da alquimia, por exemplo. Pretendemos com estas incursões embasar observações relacionadas a outro elemento importante na análise dos poemas de Lovelace: o fogo.

\section{As bruxas ontem e hoje}

Durante o período clássico, a bruxa, adoradora das deusas, aparece na literatura ocidental bem diferente de como seria vista séculos mais tarde. A teogonia de Hesíodo, por exemplo, mostra, dentre as narrativas de criação do mundo, o mito de Medeia, bruxa e sacerdotisa de Hécate, uma deusa que concedia colheitas e pescarias fartas, ampliava os rebanhos e protegia as crianças. Como esse, os mitos foram sendo transformados e acrescidos de descrições de atos de fúria, de vingança, das mais criativas perfídias e outros fatos atemorizantes; tudo contribuindo para a marginalização das crenças em um sistema sagrado feminino. Sobre o culto à deusa Diana, a deidade mais difundida na Europa, documentos foram redigidos e impostos ao longo da História pela Igreja Católica, inserindo-se em suas instruções o vocábulo diabo, associado aos cultos da deusa. Uma sucessão de fórmulas viria a se tornar tão arraigada, a ponto de, na época da Inquisiç̧ão, já ser o culto diânico sinônimo de adoração a Satanás, o que fazia com que a acusação prescindisse do devido processo e do conhecimento e exame das reais práticas pagãs.

É fato que os atributos divinos antes adorados e cultuados, como nos mostra a História, passam a ser rejeitados e reprimidos com a instauração e fortalecimento da sociedade patriarcal e das religiões monoteístas. Sob o jugo daquela nova ordem social e religiosa, em que a mulher perderia todos seus direitos e até sua própria voz, aqueles modelos femininos da Mitologia, de deusas poderosas e temperamentais, que tudo podiam e que comandavam suas próprias vidas de 
forma livre, inovadora e transformadora, passaram a ser considerados inaceitáveis e, logo, proibidos.

Ao invés de respeitadas, as matriarcas, curandeiras ou xamãs, parteiras, benzedeiras, agricultoras e praticantes de toda sorte de costumes e religiosidades antigas, denominadas feiticeiras, mulheres até então politeístas, passaram a ser temidas e, ao mesmo tempo, marginalizadas, mesmo dentro de suas próprias comunidades. Uma vez articulada a perseguição política e instaurado o poder patriarcal, não era conveniente manterem-se feiticeiras nas comunidades.

A História registrou os terríveis episódios de perseguição, principalmente das mulheres, praticantes de religiosidades pagãs. Os casos eram julgados em tribunais eclesiásticos e antes das sentenças de enforcamento ou de queima das condenadas em fogueiras, as acusadas eram sujeitas a várias sessões de tortura. Foi a lamentável parte da História chamada popularmente de Caça às Bruxas.

No Brasil, recentemente, uma pesquisadora da Universidade de São Paulo, a filóloga Narayan Porto, deparou-se com um processo do Século XVIII, mais exatamente de 1754 , aberto na cidade de Jundiaí-SP, contra uma mulher e sua filha, ambas acusadas de terem levado o marido e pai à morte com o uso de rituais de bruxaria. Os documentos foram encontrados na Cúria Metropolitana e o processo era de jurisdição do Santo
Ofício. Tratou-se, portanto, de um processo-crime em nossa história recente, no qual se verifica, também pela análise de uma das orientadoras da pesquisa, professora Dr. ${ }^{-}$Nathalia Fernandes, e do filologista e professor Aldair Rodrigues, historiador da Universidade Estadual de Campinas - UNICAMP, que as acusações eram todas da família do falecido. Tratava-se, na realidade, de uma disputa pelos bens por ele deixados. Esta referência nos interessa na presente pesquisa para demonstrar como, de fato, era conveniente e quase eficaz a acusação de bruxaria por questões das mais diversas, fossem elas sociológicas, políticas ou religiosas, submetidas a uma instituição julgadora mantida e regulamentada pela Igreja.

Com estas breves incursões, mas que, em nosso entendimento, são observações históricas e mitológicas interessantes para o tema, voltamos à abordagem literária - área de conhecimento e prazer inspirada na inesgotável e diversificada fonte da Mitologia.

Vejamos, a partir deste momento, a maneira como a figura mítica da bruxa é inserida na Literatura e, especialmente, no recorte que fazemos dos poemas de Amanda Lovelace, ${ }^{1^{*}}$ autora que conquistou seu público com a abordagem de vários temas diretamente relacionados aos conflitos e lutas - entenda-se, aqui, aos poderes - da mulher moderna.

Nas relações que estabelece entre Literatura e Mitologia, Lovelace (2018) 
sugere que não se vira, hoje, a página negra da Inquisição, mas apenas se invertem os papéis de quem detém o poder de queimar e subjugar o outro. Nesta perspectiva, cabe a pergunta: não fora o subjugo referido do passado um repulsivo ato por desejos escusos e egoístas, do assediador e usurpador? Num primeiro momento, talvez se pudesse dizer que a mobilização para a destruição do inimigo pelo fogo era um procedimento justo.

Vejamos, nos poemas, como essas questões se colocam. Agrupados em quatro partes distintas, os poemas estão distribuídos em: (I) julgamento; (II) a queima; (III) a tempestade de fogo; e (IV) as cinzas.

Os textos poéticos inscrevem o sentimento de indignação diante do assédio moral, físico e social do homem contra as mulheres. Eles fazem referência, também, a fatos contemporâneos como o feminicídio, o assédio e o estupro, registrando um tipo de comportamento responsável por reações de repúdio e indignação que tem se estendido por séculos. Utilizando-se da figura da bruxa para referir-se às condenações das mulheres à fogueira, esses textos percorrem acontecimentos do passado e sugerem analogias com fatos atuais. A linguagem utilizada nos poemas remete o leitor à História de perseguição, condenação, tortura e penas impostas às mulheres acusadas de bruxaria.
A mulher contemporânea é comparada a animais, possivelmente selvagens, que evoluem para conseguir sobreviver no ambiente em que habitam e que, dadas as circunstâncias, podem ter aprendido a revidar. A ira da deusa Ártemis, deusa da mitologia grega, cujo epíteto mais usado é de deusa da caça, é citada e o ciclo de aprendizado, próprio do mito, é lembrado - de mãe para filha. Retomamos, resumidamente, a essência do surgimento do mito de Ártemis, o qual se agrega à linha de interpretação presente. Filha de Letos e Zeus, gêmea de Apolo, foi dada à luz em meio a muito sofrimento no trabalho de parto. Conta o mito que Ártemis fora a primeira a nascer e que ajudara a mãe a continuar os esforços para o nascimento de seu irmão Apolo, como sabemos, deus símbolo da beleza masculina. Pois bem, diante de tanto sofrimento, Ártemis pede a Zeus que a libere da maternidade. Será também conhecida, em outras passagens da mitologia, como opositora de Afrodite, deusa do amor, da sensualidade e fertilidade. Dedica-se à caça, e carrega o conjunto de arco e flecha mais certeiro dos mitos, símbolo de seu caráter guerreiro e ousado. O paradigma de deusa virginal, entretanto, não impede que seja cultuada como protetora dos partos e, também, defensora da mulher parturiente.

Observemos trechos dos poemas. Antes da parte designada $O$ Julgamento, coloca-se a premissa os corpos femini- 
nos são uma posse sempre vulnerável à violência dos homens, seus predadores. Portanto, as mulheres devem declarar guerra.

\section{Profecia I}

\section{[...]}

Não podem tirar das mulheres erradas a ira de ártemis, deusa da caça (ndo aqueles que vêm para cima de mulheres como eu com olhos cheios de raiva). posso não sobreviver aos fósforos, mas meu fogo de vadia vai sobreviver a todos eles. (Lovelace, 2018, p. 23)

\section{Profecia II}

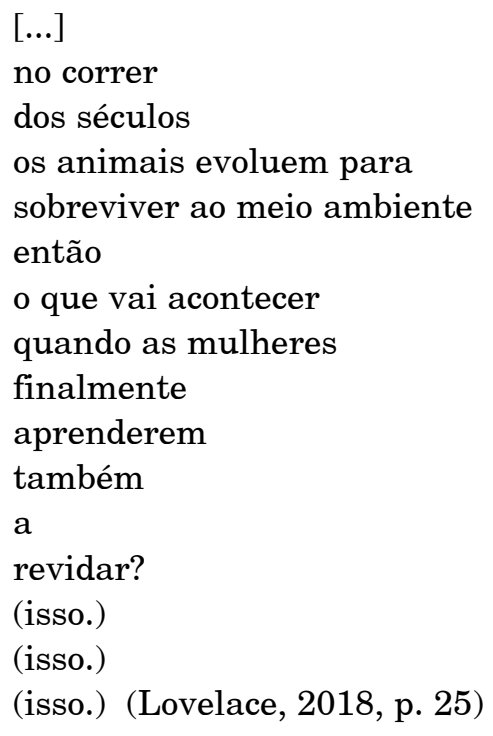

O que transparece de forma marcante no poema é o desejo imitativo, tratado na teoria mimética de René Girard (2009), que nos inspira para esta análise da estrutura do mito da bruxa aplacada pela condenação à fogueira.

Richard J. Golsan, em seu Mito e Teoria Mimética - Uma introdução ao pensamento girardiano, esclarece a dinâmica da busca pelo objeto de desejo entre opositores no mito. Assim, o desejo pelo objeto que o outro possui, não sendo original, requer a destruição de quem o detenha, "gerando atos de violência unânime e sacrificatória cometidos contra vítimas inocentes ou, noutras palavras, bodes expiatórios" (2014, p. 22).

A dinâmica do desejo imitativo é triangular, um sujeito imita o desejo de outro tomado como modelo, lendário ou histórico, extraindo deste o modus operandi para a persecução do objeto desejado. Tal dinâmica é observada em diversas áreas de estudo, como na sociologia, antropologia, psicologia, teologia e na crítica literária. Desta última, retiramos o percurso de nosso interesse, em contextos literários, conforme menciona Golsan a respeito de Mentira romântica e verdade romanesca, de René Girard, no qual o autor nos mostra os mecanismos mimético e expiatório em clássicos da literatura.

Para a crítica literária, acreditamos interessar a influência da abordagem eleita na formação social e cultural, ao reconhecermos os textos literários, também, como formadores de opinião e 
influenciadores de comportamento, direcionados à inspiração do autor e do leitor.

Observamos nos poemas, que o objeto de desejo é "os fósforos", símbolo, ali, do poder de subjugar, exterminar, anular e dominar a mulher, reprimindo sua liberdade e autoestima. O homem, gênero masculino, é transformado em bode expiatório a ser imolado para redenção de toda a formação cultural e de todos os equívocos históricos de que falamos. A inversão, conquanto poética, dos papéis violentos, nos parece clara em trechos de conspiração e incitação para que haja um revide à repressão.

Quando a rivalidade culmina na violência, a simetria fica ainda mais clara. À medida que se atacam, os antagonistas se tornam meras imagens especulares um do outro. A violência apaga as distinções que perduram entre eles. As diferenças de prestígio social, idade e sexo se vão ou se tornam insignificantes. Essencialmente indistinguíveis entre si, os antagonistas não passam, agora, de duplos violentos. (GOLSAN, 2014, p. 63)

Vejamos o percurso que justifica o desejo mimético. "Os caras dos fósforos" é uma expressão recorrente para indicar os homens. Na parte designada "a queima", indica-se o assédio moral e cultural por meio da exigência da beleza perfeita, assim como a boa forma e delicadeza, como atributos obrigatórios para as mulheres. Ressalta-se, ainda, nessa perspectiva, o quanto as mulheres são humilhadas em função deste conjunto de comportamentos e qualidades que devem oferecer. eles

nos dizem

mais uma \& mais uma

$\&$ mais uma

vez que as mulheres

precisam

ficar

pequenas /

finas /

muito magras /

diminutas

assim

somos

facilmente

colocadas no bolso

para ser usadas

$\&$ jogadas fora

mais

tarde.

curvas

$\&$ gorduras

$\&$ pneus

São um

Colossal

"foda-se"

ao patriarcado...

nossa rebelião inesperada.

- meu corpo rejeita seus desejos. (Lovelace, 2018, p. 61)

Outras manifestações também podem ser observadas em relação ao comportamento e à imagem impostos ao ser feminino, nos mais diversos contextos e situações: a mulher, vista como mercadoria, refém de abusos romantizados, premida a submeter-se aos modelos impostos para seduzir os homens. Dentro desses 
padrões, e somente assim, é considerada hábil na arte da sedução. Todavia, na arte de seduzir acontece de atrair até mesmo seus estupradores, que são inocentados sob o argumento, exatamente, de serem aplacados pela sedução. Essa parte dos poemas inscreve, também, o sentimento de indignação, encorajando as mulheres a revidarem e fazerem uma fogueira bem grande para queimar todos aqueles que tentaram castigá-las. O castigo: a fogueira para eles.

é isso mesmo,
sou
a mulher
com o coração incendiário
sobre o qual todos os seus pais lhe
advertiram
$\&$
quando uma árvore
pega fogo,
não demora muito
para que

toda a floresta

esteja em chamas

- ainda assim nunca me importo com quem se machuca. (Lovelace, 2018, p. 35)

O fogo é mencionado em variantes de significação e, com frequência, apresenta conotação sexual e passional - um estopim simbólico muito conhecido na literatura para falar das paixões e tentações. Por outro lado, é possível observar que não existe menção ao fogo transfor- mador de uma forja, mas, predominantemente ao dos homens dos fósforos, ou seja, castradores e déspotas. Seria, sim, o fogo da destruição e da tortura.

Importante nos parece destacar, ain$\mathrm{da}$, que o estudo revela a escolha feita pela autora que, ao se inspirar em uma figura mítica como a bruxa, utiliza-a num processo verdadeiramente criativo. É nesta direção que reiteramos a figura mítica da bruxa a serviço da etimologia do vocábulo tal como seria conveniente aos processos da Santa Inquisição, isto é, a bruxa do verbo bruciare, ligada ao fogo de extermínio. Assim fazendo, a obra retoma mais o sentido pejorativo da figura, mulher má, vingativa, capaz de usar seus poderes para destruir e do mesmo modo que seus carrascos, condenar, humilhar e queimar.

Nos poemas selecionados, não encontramos associação com a mulher-bruxa a ser valorizada e reinserida no mundo moderno como a verdadeira heroína histórica, credora de espaço e segurança para cumprir seu papel social. Longe disso, observamos neste estudo que o uso poético de elementos como o fogo, a fogueira e os "caras dos fósforos" indicam uma trajetória de indignação e destruição. Com a ampliação do olhar histórico e mitológico, propomos a reflexão acerca da ambivalência da figura mítica da bruxa, e nos debruçamos sobre seu estatuto ao longo dos tempos na criação literária. 
A alusão ao mito da bruxa nos poemas de Lovelace não nos parece inspirada na estrutura da jornada do herói de Campbell, ou nos mitos das deusas heroínas. E, consequentemente, o fogo nos poemas igualmente não remete às simbologias mitológicas para este elemento como, por exemplo, a forja, a transformação, a luz e o calor que protegem contra o inverno. Neste estudo queremos trazer a lume outra categoria de mulher-bruxa que também possa inspirar com mais frequência a criação literária, o papel da bruxa mitológica, cujas práticas de valorização do feminino foram interrompidas por perseguições, na maioria das vezes injustas. Ao observarmos o percurso proposto nos poemas, compreendemos o fenômeno a partir do estudo do desejo mimético e do mecanismo expiatório da teoria girardiana em oposição ao que ousamos pensar, remetendo-nos à obra de Campbell, como a jornada da heroína, potencialmente detentora do poder de seu mito.

A partir do exposto até aqui, impõe-se uma questão de cunho não apenas social, mas também mítico-cultural: poderia a mera transformação do gênero masculino em bode expiatório redimir uma sociedade machista, em países laicos que fazem censura velada, por omissão, a outras manifestações religiosas e artísticas? Que perpetra todos os tipos de fogueiras, acesas não só por homens, como também por mulheres em nome e
Estados e de instituições, em detrimento da valorização do feminino?

O papel da figura mítica ou histórica da bruxa, tal como aparece nos poemas não nos chamaria a atenção, fosse sua presença em um conto de fadas ou conto popular no qual a bruxa ocupasse o papel de opositora - considerando-se aqui a composição da literatura fantástica. Este artigo, diferentemente, trata da inspiração na Mitologia e, mais especialmente na figura mítica da bruxa, para criações literárias que lidam com elementos e contextos reais.

Por se tratar de poemas de literatura feminista, queremos ressaltar que não nos referimos à mulher-bruxa como coadjuvante na jornada do herói masculino. A hipótese refere-se a uma estrutura básica na literatura infantil, por exemplo, na qual a bruxa costuma exercer o papel do opositor.

O desejo mimético da mulher-bruxa, de subjugar e destruir para apropriar-se justamente do poder que tanto lhe causou repulsa, engendra uma teoria da conspiração em forma de poemas, para uma vitória de Pirro - Pirro de Epiro ou Pirro de Élida. Lembremos, já que nos aventuramos no terreno da mitologia, que a vitória pírrica é aquela que nos remete ao mito registrado a partir de um fato histórico da Grécia antiga, quando o general e depois rei Neoptólemo, filho de um semideus, Aquiles, conhecido como Pirro, teria constatado que, ao ganhar 
certa batalha à custa de muitas perdas, sua conquista se desvalorizara. Seu mito deu origem a expressões como vitória de pirro ou vitória pírrica. Atentos à sabedoria mítica, podemos comparar o Pirro de Epiro ao Pirro de Élis ou Élida. Existiu outro Pirro, um filósofo de Élis, também da Grécia antiga, conhecido por seu ceticismo, que defendia a tranquilidade da indiferença, sem buscar o certo e o errado, afirmando não existir verdade absoluta. Apenas para ilustrar a referência, alguns resumos sobre seu pensamento nos ensinam que mais vale um estado de dúvida permanente e de alerta contra dogmas à belicosidade crônica. Conta-se que sua capacidade de se manter calmo nas situações mais adversas, era extraordinária. Daí pensarmos em opor a vitória de Pirro de Epiro à vitória de Pirro de Élis, que viveu até 90 anos de idade.

Ao tentar avaliar a influência do desejo mimético sobre o desenvolvimento da cultura e das instituições sociais nas duas principais obras que publicou nos anos 1970, A Violência e o Sagrado (1972) e Coisas Ocultas desde a Fundação do Mundo (1978), Girard se viu obrigado a lidar desde o início com um problema enorme: o potencial destrutivo do desejo mimético. Se a imitação dos outros conduz inevitavelmente à rivalidade e ao conflito, e se todos os homens agem mimeticamente, a humanidade como um todo parece fadada a um círculo infindo de competição e violência. É difícil conceber sob essas condições, tanto a sobrevivência humana quanto a gênese e o desenvolvimento da cultura. (GOLSAN, 2014, p. 59)
No caso, vislumbramos que o engajamento literário subjacente, de cunho notoriamente feminista, se beneficiaria desta reflexão com a exploração de outros atributos de todo o caldeirão de possibilidades da figura da bruxa, quiçá prescindindo de eleger, de modo genérico, um bode expiatório.

\section{O fogo}

A criação de uma bruxa dos fósforos definitivamente não nos remete a fogos míticos carregados de simbologia de poder de cura e de transformação. Não foi este o fogo eleito no recorte mítico dos poemas da "bruxa que não vai para a fogueira". Mesmo assim, revisitamos, nesta comparação, o fogo a que nos referimos nos mitos das deusas antigas.

A primeira delas aqui lembrada, a deusa Brigit, da mitologia celta, também uma deusa irlandesa muito popular, por fazer parte da história do surgimento da Irlanda, traz nas imagens que a representam, o fogo nas mãos, o qual se consagra, na História e na Mitologia, como a Chama de Brigit. Tão forte e arraigado o seu culto que, acredita-se, tenha sido absorvido nas celebrações cristãs como Santa Brígida, padroeira da Irlanda, ultrapassando barreiras filosóficas e religiosas. Para os povos celtas, o fogo era símbolo de todas as fontes de inspiração e conexão divinas. Os símbolos que remetem à Santa Brígida, inclusive, coin- 
cidem com aqueles da deusa da Irlanda pagã, sendo a chama eterna um destes. Até mesmo o dia da Santa, 01 Fevereiro, é o mesmo da celebração pagã da deusa, data em que se celebra também o sabat de Imbolc, festival pagão que anuncia a primavera. Até hoje se pode visitar em Kildare, na Irlanda, um convento onde freiras mantêm acesa uma chama em honra a Santa Brígida. Eis a presença do fogo que não se apaga e não se exaure na produção de cinzas apenas, é cuidado para manutenção da memória histórica, e como não considerarmos, do poder do mito.

Hécate, deusa da mitologia grega, é conhecida por alcunhas diversas, sendo a maioria ligada ao submundo, à escuridão e ao túnel que se deve pegar após a morte. Sua ligação com a escuridão é representada na sua imagem com duas tochas nas mãos, dentre outros símbolos, para iluminar os caminhos tenebrosos, guiando seus cultuadores pelos caminhos da morte. Adorada na Grécia antiga como protetora dos lares é também evocada como protetora dos campos e plantios por ser a grande deusa dos dois mundos - da vida e da morte.

Pretendendo dar um panorama cultural um pouco mais estendido, acrescentamos também nestas incursões, a deusa Amateratsu, divindade mitológica mais conhecida do Japão e adorada no xintoísmo, cujo mito a coloca como a deusa do sol e detentora do fogo que ilumina o mundo, além de criadora do Japão, terra do sol nascente. Culturalmente, atribui-se a ela a semente do alimento mais importante na Ásia, o arroz, bem como o sucesso de suas colheitas. Em determinada passagem de seu mito, por ter sido contrariada, fecha-se em uma caverna e deixa o mundo no frio e no escuro, até que a humanidade aprenda a lição e vá até ela, rendendo-se à sua sabedoria.

Finalmente, e sem pretensão de esgotar exemplos mitológicos do fogo e seus significados na mitologia, lembramos Héstia ou Vesta, da mitologia greco-romana, deusa sagrada do fogo das lareiras, do lar, da família, da vida doméstica. $\mathrm{O}$ fogo ligado a ela é o que aquece os lares e templos, simbolizando o afeto que cria a aura de aconchego das casas, o calor feminino do acolhimento. Estamos cientes do sentido pejorativo que é atribuído ao fogo/afeto da dona de casa ou mulher do lar na atualidade, compreendido como papel menor que restringe sua força de trabalho intelectual e de atuação política. Porém, tratamos de mitos, histórias antigas, trabalhando sobre fatos históricos e culturais e, assim, buscamos na essência do relato também a compreensão do atributo feminino da agregação e fortalecimento da família, em qualquer modelo e formação. Héstia está entre as 12 divindades do Olimpo, considerada a chama da proteção. 
o julgamento

[...]

eles não sabem o que vem por aí, que fofos. nós não devemos ter medo deles.

não não não.

eles é que devem ter medo de nós.

- a primeira lição do fogo.

nós damos poder

a tudo que

queremos,

mas também podemos

tirá-lo

novamente,

$[\ldots]$

(Lovelace, 2018, p. 28-29)

A respeito das cinzas colhidas dos poemas de Lovelace, elas nos pareceram de desolamento, embora se pretenda, com elas, um convite à resistência pela arte ou, mais especificamente, pela poesia. Impacta-nos que o desafio da resistência pela arte seja colocado nas mãos de necromantes.

eles

disseram

a poesia

está morta,

então

as mulheres

cansadas

mas sempre determinadas tomaram isso

como um

desafio

\&

se uniram

para dar à luz

seu encantamento

de ressurreição.

- necromantes. (Lovelace, 2018, p. 165)

Com os versos da parte final do livro - IV as cinzas - encerramos nossa reflexão, desejando dar à luz um encantamento de ressureição de novas leituras dos mitos e análises de discursos que provoquem autores e leitores a continuarem explorando a riqueza das narrativas mitológicas.

\section{Considerações finais}

Os poemas objeto deste artigo, embora inicialmente apresentem um título que provoca no leitor à expectativa de coragem e de salvação de uma heroína, engendram o desejo mimético fazendo surgir um bode expiatório. Propusemos, neste estudo, problematizar esta expectativa, assim o fazendo mediante a demonstração de outra possibilidade de abordagem do mito da bruxa na literatura, debruçando-nos na História, nos relatos da Mitologia e na estruturação da jornada do herói, de Campbell. Traçamos a base histórica do percurso da mulher-bruxa, ousando trazê-la ao presente 
pela contemplação de uma jornada da heroína. Em oposição, o exemplo escolhido nos poemas forma o duplo violento, mencionado por Golsan, nos seus estudos introdutórios à teoria mimética de René Girard.

$\mathrm{Na}$ linguagem poética, e é especialmente nela que nos apoiamos nesta análise, tanto o fogo como as cinzas dos poemas imprimem em nossas mentes os significados do contexto em que aparecem - violento e desolador. Neles, o fogo é a ferramenta do duplo violento e da conspiração para a destruição do bode expiatório eleito. Assim analisada, queremos demonstrar que a base mitológica da bruxa queimada nas fogueiras da Inquisição não é a única base dessa figura.

Refletimos, pois, no impacto da autora ao trazer a necromancia para encerrar seu poema, e na maneira como a significação da morte impacta o leitor. Prática de invocação dos mortos para adivinhações do futuro, o vocábulo vem das palavras gregas nekrós (cadáver) e mantéia (profecia). O ritual ficou conhecido, de fato, entre os gregos, sob a crença de nele se obterem respostas do morto.

Desejamos e buscamos contribuir para que a poesia não esteja morta, que se faça presente, sempre viva, reafirmando que o pensamento poético é o sangue que corre nas veias da arte. Em todas as suas possibilidades, possa o mito cumprir seu papel de renovação cíclica da nossa existência e criatividade.

\section{The figure of the witch from the perspective of René Girard theory, on Amanda Lovelace's poems}

\section{Abstract}

This article approaches the representation of the witch in literature, and in the poems published under the title "The witch doesn't burn in this one", by Amanda Lovelace. We stem from a short overview of the studies by Joseph Campbell, before focusing on the concepts of power, as an object of desire, and according to the theory of mimetic desire by René Girard. This article brings historical data and the etymological origin of the word 'witch', fundamental to the interpretation carried out in this study, in which the power desired is that of controlling the destructive fire, in opposition to the fire of transformation, also from the myths of goddesseswitches. Finally, we proceed to the analysis of the feminine subject in the poems, together with the parameters which guided us to recognize a "scapegoat", who emerged in between the journey of the witch during the Inquisition fires and the current male gender, represented in the poems by the metaphor "match-boys".

Keywords: Witch; Mythology; Feminism; Myth and mimetic desire; Amanda Lovelace.

\section{Notas}

1 Amanda Lovelace é uma poeta norte-americana que foi nomeada Poeta do Ano, pela Goodreads. Ela é a autora da coleção "As mulheres têm 
uma espécie de magia”, tendo se destacado como vencedora do Prêmio Goodreads com "A princesa salva a si mesma neste livro". Ganhou uma legião de fãs graças às redes sociais, com mais de 80 mil seguidores no Instagram.

\section{Referências}

BARROS, Maria Nazareth Alvim de. As Deusas, as bruxas e a Igreja: séculos de perseguição. 1a ed. Rio de Janeiro: Rosa dos Ventos, 2001.

BRANDÃO, Junito de Souza. Mitologia Grega. 9ª ed. Vol. I. São Paulo: Vozes, 1994.

CAMPBEL, J. O Poder do Mito. Versão digital Le Livros da $2^{\mathrm{a}}$ ed. São Paulo: Palas Atena, 1991.

A Jornada do herói. 1ํㅡㄹ ed. São Paulo: Ágora, 2004.

CORDEIRO, Tiago. Como é um ritual de necromancia. Super.abril.com.br, 2020. Disponível em <https://super.abril.com.br/ mundo-estranho/como-eram-os-rituais-de-necromancia/>. Acesso em 30/05/2020.

GIRARD, René. Mentira Romântica e Verdade Romanesca. Tradução de Lilia Ledon da Silva. 1ª ed. São Paulo: É Realizações, 2009.

GOLSAN, Richard J. Mito e Teoria Mimética - Uma introdução ao pensamento girardiano. Tradução de Jugo Langone. $1^{\mathrm{a}}$ ed. São Paulo: É Realizações, 2014.

GRIMASI, Raven. Enciclopédia de Wicca e Bruxaria. Tradução de Marcelo Giusepp Lichinski, São Paulo: Gaia, 2004.

LIBERMAN, Anatoly. The Oxford Etymologist goes Trick-or-Treating. University Press's Academic Insights for the Thinking World. 2007. Disponível em <https://blog.oup. com/2007/10/witch/>. Acesso em 18/03/2020.

LOVELACE, Amanda. A bruxa não vai para a fogueira neste livro. Tradução de Izabel Aleixo. $1^{\mathrm{a}}$ ed. Rio de Janeiro: LeYa, 2018.
PORTO, Narayan. Feitiçaria paulista: transcrição de processo-crime da Justiça Eclesiástica na América portuguesa do século XVIII. 2018. 370 f. Dissertação (Mestrado em Filologia e Língua Portuguesa) - Faculdade de Filosofia, Letras e Ciências Humanas. Universidade de São Paulo, São Paulo.

SARTRE, Jean Paul. O que é a literatura. Tradução de Carlos Felipe Moisés. Edição digital. Petrópolis: Vozes, 2015.

WOOLGER, Roger; Jennifer Barker. A Deusa Interior. Tradução de Carlos Afonso Malferrari. $1^{\mathrm{a}}$ ed. ( $9^{\mathrm{a}}$ reimpressão). São Paulo: Cultrix, 2007. 